\title{
Efficacy of Interactive Whiteboard on Psychomotor Skills Achievement of Students in Isometric and Orthographic Projection
}

\author{
Isiaka A. Gambari, Sherifat A. Balogun, \& Ahmadu S. Alfa \\ Federal University of Technology, Nigeria
}

\begin{abstract}
This paper discusses importance of technology education and evidences of declining performance of junior secondary school students in basic technology subject. Potentials on interactive whiteboard (IWB) as one of the new technologies to meet the challenges of the $21^{\text {st }}$ century are also discussed. The efficacy of IWB for teaching Isometric and Orthographic projection concepts in Technical Drawing aspect of Basic Technology was determined using a pretest-posttest, non-equivalent, non-randomized quasi-experimental design. A 2×2×3 factorial design was employed. Ninety Four (49 males and 45 females) and (31 high, 51 medium and 12 low achievers) JSS-1 students from two secondary schools in Abuja Metropolis made-up the sample. The schools were randomly assigned to experimental and control groups. The experimental group was taught selected concepts of Isometric and Orthographic Projections using IWB and (Chalkboard) traditional method were used for the control group. A validated Basic Technology Achievement Test (BTAT) comprised of 25-item multiple-choice object test was employed for data collection. The reliability coefficient of BTAT was 0.88 using Kuder-Richardson (KR-20). The hypotheses were tested using ANCOVA and Scheffe post-hoc analysis. Results revealed that the students taught with IWB performed better than the control group. Also, high achievers performed better than medium and low achievers respectfully. The IWB was found also to be gender friendly. Based on the findings, it was recommended that the use of IWB should be encouraged in Nigerian schools.
\end{abstract}

Keywords: Interactive whiteboard; Isometric and Orthographic; Psychomotor skills; Gender; Achievement levels

\section{Introduction}

The role of science and technology cannot be overemphasized. Nigerian government realized the paucity of technology for national development and this made her to integrate Basic Technology into Junior Secondary School education curriculum. Basic Technology comprised of Technical Drawing, Woodwork, Metalwork, Building Technology, Auto Mechanic, and Electrical/Electronics. Technical Drawing is one of the aspects of Basic Technology that students find difficult to pass because it requires psychomotor skills (FRN, 2009).

Psychomotor skills in technical drawing involve activities that need coordination of finger and hand movement as a result of cognitive planning. The activities might include several tasks such as bisecting, measuring, pencil work, link mechanism, drawing to scale, lettering, dimensioning, freehand sketch, etc. Drawing Isometric from Orthographic and converting 
Orthographic to Isometric components is one of the areas students find difficult to understand (NECO, 2010, 2012).

The trends of the previous junior secondary certificate examination (JSCE) results in Abuja revealed students' low enrolment level for Basic Technology in JSCE and poor performance in the subject at credit level (NECO, JSCE results 2007, 2008, 2009, 2011, 2012 \& Ajani, 2009). The causes of poor performance have been attributed to lack of interest in the subject or lack of understanding of the subject due to its abstractness as a result of poor school infrastructure, poorly equipped workshops, non-availability and utilization of instructional materials, lack of qualified personnel (teachers and workshop assistants), and poor instructional strategies (Abassa, 2011; Akpan, Mbaba, \& Udofia, 2012; Balogun, 2007; Kiadese, 2011). By implication, if care is not taken, the dream of preparing Nigerian youths to face the unfolding technological challenges may not be realized.

Information and communication technology is becoming part of the daily life in contemporary educational institutions across the globe. In Nigeria, the earliest initiative in this direction was the pilot scheme in the Federal Government Colleges in 1987 which was preceded with training programs for 197 teachers (Yoloye, 1990). In the year 2004, the Federal Ministry of Education released a document termed the ministerial initiative on e-education for the Nigerian education system. This document was an approval in principle for e-education project for the Nigerian education system. Of recent new in initiatives like Opon Imo - Tablet of Knowledge, in Osun State (Aregbesola, 2013), solar and electronic classroom, e-classroom in Lagos State (Olowoopejo, 2014), among others, have led to greater interest in the application of ICT in Nigerian schools. Since the 1987 initiative, the process of ICT integration in Nigeria schools has been very slow. There is still lack of evidence that ICT can actually enhance students' performance, particularly in technology education where students' performance in public examination is poor. To improve on the achievements of students in technology education related subjects in Nigeria, it is necessary to have a paradigm shift and join the developed world in embracing interactive whiteboard for teaching and learning.

In Nigerian schools, chalkboard is the common method of presentation. There are problems of availability, accessibility and usability of the Interactive Whiteboard (IWB). Yanda (2012) reported the availability of the IWB technology in Niger State, Nigeria. Out of 152 secondary schools in the State, only two private secondary schools reported having and using the devices regularly. No public secondary schools in Niger State have the IWB. Although, many schools are interested to adopt the technology as a normal part of their instructional practices, but availability is still an issue in most of the schools.

Interactive whiteboard is a technology that transmits computer screen to the whiteboard by means of a projector and that enables controlling the computer by only touching the whiteboard with a special pen (Becta, 2003). The use of Interactive Whiteboards provides more opportunities for interaction and discussion in the classroom (Painter, Whiting, \& Wolters, 2005). It increases enjoyment of lessons for both students and teachers through more varied and dynamic use of multimedia and resources, with associated gains in motivation (Levy, 2002). It provides greater opportunities for participation and collaboration that led to students' personal and social skills development (Jones, 2004). IWB also, encourages spontaneity and flexibility, allowing teachers to draw on and annotate a wide range of webbased resources (Kennewell \& Beauchamp, 2003). 
Interactive whiteboard increases teaching time by allowing teachers to present web-based and other resources more efficiently (Beauchamp, 2004). It reduces the need for note-taking through the capacity to save and print what appears on the board enables teachers to save and print what is on the board, including any notes made during the lesson, reducing duplication of effort and facilitating revision (Lerman \& Zevenbergen, 2006). Students are able to cope with more complex concepts as a result of clearer, more efficient and more dynamic presentation (Smith, Hardman, \& Higgins, 2006)., different learning styles can be accommodated as teachers can call on a variety of resources to suit particular needs (Martins, 2007). It enables students to be more creative in presentations to their classmates and increasing self-confidence (Levy, 2002). IWB allows teachers to share and re-use materials, reducing workloads (Glover \& Miller, 2001). Studies have noted that the use of whiteboards shifts instruction from presentation to interaction and students' focus shift from teachers and onto content, making Interactive Whiteboard lessons more student-centered than traditional ones (Miller, Glover \& Averis, 2003; Painter, Whiting \&Wolters,2005).

Higgins (2010) reported that teachers felt that the IWB helped them to achieve their teaching aims and cited a number of factors such as the wealth of resources available, the stimulating nature of the presentation, and the flexibility that the technology offered. Ninety nine percent believed that using the interactive whiteboard in lessons enhanced students' motivation to learn. Eighty-five percent thought that interactive whiteboards would lead to improvements in student achievement. In another study, Paragin et al. (2010) reported ninety-three percent felt that the use of the whiteboard had enabled learning the course material favorably. While there were a few negative comments, those who completed the questionnaire felt that the use of SMART board has enabled the training course to exceed their expectations. Winzenried, Dalgarno, and Tinkler (2010) conducted a qualitative study on teachers' perspectives on the impact of the interactive whiteboard on their pedagogical practice. It was found that Interactive whiteboards did not appear to decrease the opportunities in teaching and learning in the classrooms. In fact, the IWB was seen as a flexible tool for the classroom. IWB technology was found to include a wider range of highly motivating and contemporary resources and levels of student engagement were greatly increased as was their learning and both were seen as consequences of the activities afforded by the IWB. Findings from a study by $\mathrm{XU}$ and Moloey (2011) indicate that the IWB has the ability to create a variety of visual activities, which has impacted the material presented. Students also reported that the IWB has enhanced the learning experience, reflected in increased motivation and engagement through interaction with this technology.

In spite of potentials of IWB, its effect on student learning is difficult to establish, since there are few, if any, rigorous studies on the impact of the IWB on student learning (Smith et al., 2005). There is conflicting information regarding the effect of IWBs on student achievement and attainment. Moreover, there are some evidences that the use of interactive whiteboards can increase student achievement. For example, Zittle (2004) reported that students taught geometry with interactive whiteboard outperformed those taught with traditional method. Similar studies across different disciplines such as Dhindsa and Emran (2006) in organic chemistry, Wood and Ashfield (2008) in literacy and numeracy, and Miller, Glover, and Averis (2003) in Mathematics reported that Interactive students exposed to Interactive Whiteboard performed better than those taught with traditional method. In supporting these findings, Wood et al. (2008) stated that the traditional model of learning emphasizes regurgitating of facts and concepts, while IWB diversifies the system of representation through the use of various stimuli (images, sounds and movement) and address the needs of diverse types of learning (visual, psychomotor, and affective). 
Contrary to these positive reports, one of the most compelling studies that showed a negligible effect of IWB on achievement is Higgins et al. (2007). After a 2 year study, no significant differences were found in test scores between schools using IWBs, and schools not using IWBs. Similarly, in a comparative study conducted by Christophy and Wattson (2007), a group of high school students who learned abstract terms in chemistry with the use of the IWB actually received lower scores on a multiple choice test of knowledge in comparison to the group that learned traditionally (without the IWB). In another study, Schuck and Kearney (2007) reported that little or no difference was found on national test scores in mathematics and science in UK primary schools when comparing IWB and non-IWB classrooms. In addition, London schools in the Secondary Whiteboard Expansion Project, where teachers were using the IWB in various ways, reported no impact on pupil performance in the first year in which departments were fully conversant with the technology (Higgins et al., 2007). Buff (2012) investigated the effects of interactive whiteboards on students' achievement. In the end, the control group consistently scored higher on the assessment piece than experimental group. This apparent lack of effect on achievement is consistent with other studies contained in this review (Glover et al., 2005b; Martin, 2007; Smith et al., 2005; Solvie, 2007). None of these studies report the effects of gender on IWB.

Gender issue as regards students' performance is one of the prevailing factors (Yusuf, Gambari, \& Olumorin, 2012). Research studies in the past have reported male dominance in achievement; however recently the situation is reversed. For instance in Nigeria, Anagbogu and Ezeliora (2007) exposed boys and girls to different scientific trainings based on cognitive, affective and psychomotor skills and found that girls scored significantly higher than boys. Similarly, in Brunei female students outperform male students in science (McNeese, 2003). Furthermore, Annetta, Mangrum, Holmes, Collazo, and Cheng (2009), Kost, Pollock and Finkelstein (2009), Ifamuyiwa and Akinsola (2008) reported that gender has no effect on academic performance of students in physics and mathematics respectively.

Students' achievement level as a cause of differential learning outcome has attracted the attention of educational researchers. In Nigeria classrooms, students with different achievement levels are mixed together and given same treatment without considering their individual differences (Yusuf, 2004). Innovative teaching strategies such as IWB that could cater for individual differences and bridge the gap between students' achievement levels should be encouraged. Studies revealed that high ability students do perform better than the medium and lower ability students (Aluko, 2004; Fajola, 2000; Gambari, 2010; Yusuf, 2004).

In Nigeria, much has not been done on the effects of instructional media on students' performance in Basic Technology. In addition, most of the studies on Interactive Whiteboard were conducted in foreign countries and very few were conducted in Nigeria especially on Technical Drawing aspects of Basic Technology. It is against these backgrounds that this study examined the effects of Interactive Whiteboard on psychomotor skills achievement of Junior Secondary School Students in Isometric and Orthographic projections in Technical drawing aspect of Basic Technology.

\section{Research Questions}

(1) What is the difference in the mean achievement scores of students taught Basic Technology with Interactive Whiteboard and those taught with chalk board? 
(2) Is there any difference in the mean achievement scores of male and female students taught Basic Technology using Interactive Whiteboard?

(3) Is there any difference in the mean achievement scores of high, medium and low achiever students using Interactive Whiteboard?

\section{Research Hypotheses}

(1) There is no significant difference in the mean achievement scores of students taught Basic Technology with Interactive Whiteboard and those taught with chalk board.

(2) There is no significant difference in the mean achievement scores of male and female students taught Basic Technology using Interactive Whiteboard.

(3) There is no significant difference in the mean achievement scores of high, medium and low achiever students using Interactive Whiteboard.

\section{Methodology}

The research design adopted for this study is a quasi-experimental design using nonrandomized, non-equivalent, pretest, posttest experimental group design. Two levels of independent primary variables (experimental and control groups), two levels of gender (male and female) and three levels of academic achievement (high, medium and low) were investigated on students' performance in Basic Technology. The research design layout is as shown in Table 1.

Table 1. Research Design Layout

\begin{tabular}{llll}
\hline Groups & Pre-test & Treatment & Post-test \\
\hline Experimental & $\mathrm{O}_{1}$ & Interactive Whiteboard & $\mathrm{O}_{2}$ \\
Control & $\mathrm{O}_{3}$ & Chalkboard & $\mathrm{O}_{4}$ \\
\hline
\end{tabular}

Purposive sampling technique was used to select two schools in Abuja municipal area council (AMAC) for the study. The schools were sampled based on (facilities and manpower), school type (public schools), gender composition (co-educational schools). The two schools were randomly assigned to experimental group (IWB group) and control group (chalkboard group) respectively. Intact classes of the students classified into gender (males and females) and achievement levels (high, medium and low) were used. The distribution of sample for the study is shown in Table 2 .

Table 2. Distribution of Sample for the Study

\begin{tabular}{llllll}
\hline Groups & \multicolumn{3}{c}{ Gender } & \multicolumn{3}{c}{ Achievement Levels } \\
\hline \multirow{2}{*}{ IWB } & Male & Female & High & Medium & Low \\
\cline { 2 - 6 } & 18 & 21 & 16 & 18 & 5 \\
CB & 31 & 24 & 15 & 33 & 7 \\
\hline
\end{tabular}


From Table 1, the groups comprised a total of 94 students, 39 students were exposed to Interactive Whiteboard (IWB) (Experimental Group), 55 students were exposed to Chalkboard as a delivery medium (Control group).

Students were stratified into academic levels (high, medium and low) based on their performance in the last promotion examination in basic technology course. The high level students, in this study were the ones whose average scores in previous school examination in basic technology fall within the upper $25 \%\left(3^{\text {rd }}\right.$ quartile). The medium achievement level students' scores were within the middle $50 \%$, while students whose scores fall within the lower $25 \%$ ( $1^{\text {st }}$ quartile) were classified as students in low achievement level.

\section{Research Instruments}

The Interactive Whiteboard (IWB) with the Isometric and Orthographic contents was installed in the system. The teacher presents information and displays animation of the contents in 3dimensional view to the learners using IWB on each of the eight sub-units after which the students demonstrated the skills one after the other at the end of each unit.

The instrument that was used in collecting data for the study was researcher developed Basic Technology Achievement Test (BTAT). The BTAT consists of section 1 and 2. Section 1 consists of students' Bio data. The Bio data was designed to obtain the students' data such as Name of school, class, sex, stratum of student. Section 2 of BTAT consists of 25-multiple-choice objective test items with five options (A-D). BTAT was validated by experts in Industrial and Technology Education Department, Federal University of Technology, Minna; Basic Technology subject teachers; and Test and measurement specialists from National examination Council. Its reliability coefficient was determined as 0.84 using Kuder Richardson (KR-21).

The researchers visited the schools to be used for the research and sought for permission from the school Principals. Basic Technology teachers and students were briefed on the objectives and modalities of the experiment. The researchers taught the students based on the lesson plan for four weeks using Interactive Whiteboard for the experimental group and Chalkboard for the control group. The researcher administered the Basic Technology Achievement Test (BTAT) on sample students as pretest to ascertain the equivalence of the students before the treatment. The lessons were delivered by Basic Technology teachers with the help of research assistants. The following are the experimental procedures for each group:

Experimental Group 1: The IWB contained all the drawing instruments which were picked to demonstrate and explain the drawing. The teacher demonstrated and also called the students to do the same. It actually allowed the class to be participatory and interesting.

Control Group: The Chalkboard lessons were delivered using drawing instruments. The teacher explained and drew some Isometric drawings and asked the students to reproduce it, the class was also participatory. The same was done in the Orthographic projection lessons.

Immediately after the treatment, BTAT was administered as posttest to measure the achievement of the sample students in each group. The scores obtained were subjected to data analysis. The data were analyzed based on the stated hypotheses, using ANCOVA. Where 
differences were established, Scheffe's post-hoc was used to locate the direction of the differences. Graphical representations were also used to show some illustrations. The significance of the various statistical analyses was ascertained at the 0.05 alpha level.

\section{Results}

The results are presented in line with the formulated hypotheses:

$\mathbf{H o}_{\mathbf{1}}$ : There is no significant difference in the mean achievement scores of students taught Basic Technology with Interactive Whiteboard and those taught with chalkboard.

To determine whether there was significant difference in the post-test mean scores of the experimental (Interactive Whiteboard, IWB) and control groups (Chalkboard), data were analyzed using the analysis of covariance (ANCOVA). Table 3shows the result of the analysis.

Table 3. ANCOVA of Post-test on Experimental (IWB) and Control (Chalkboard) Groups

\begin{tabular}{llllll}
\hline $\begin{array}{l}\text { Source of } \\
\text { Variation }\end{array}$ & Sum of Square & df & Mean Square & $F$ & Significance \\
\hline $\begin{array}{l}\text { Covariate } \\
\text { (Pre-test) }\end{array}$ & 6799.816 & 1 & 6799.816 & 106.421 & 0.000 \\
$\begin{array}{l}\text { Main Effect } \\
\text { (Treatment) }\end{array}$ & 4769.191 & 1 & 4769.191 & 74.640 & 0.000 \\
Model & 6892.713 & 2 & 3446.356 & 53.937 & 0.000 \\
Residual & 6197.877 & 97 & 63.896 & & \\
Total & 406345.000 & 100 & & & \\
\hline
\end{tabular}

Table 3 shows that an $F(1,97)=74.640, p<.05$ for the main effect (treatment) was significant, this indicates that the method of instruction produced a significant effect on the achievement scores of students when covariate effect (pre-test) was controlled. The result indicates that there was significant difference between students exposed to IWB and those exposed to Chalkboard.

The performance of students in the two groups was further compared and the results are shown in Table 4 and graphically illustrated in Figure 1.

Table 4. Mean Gain Scores of Students Taught Physics Using IWB and Chalkboard

\begin{tabular}{lllc}
\hline Group & Pre-test & Post-test & Mean Gain Score \\
\hline IWB & 18.00 & 61.64 & 43.64 \\
Chalkboard & 9.98 & 63.58 & 53.60 \\
\hline
\end{tabular}

Table 4 shows that, the groups had improved performance in post-test. For instance, IWB had the mean gain score of 43.64 while Chalkboard had the mean gain score of 53.60. This 
indicates that all the groups benefited from the treatment, with chalkboard group having slight high performance.

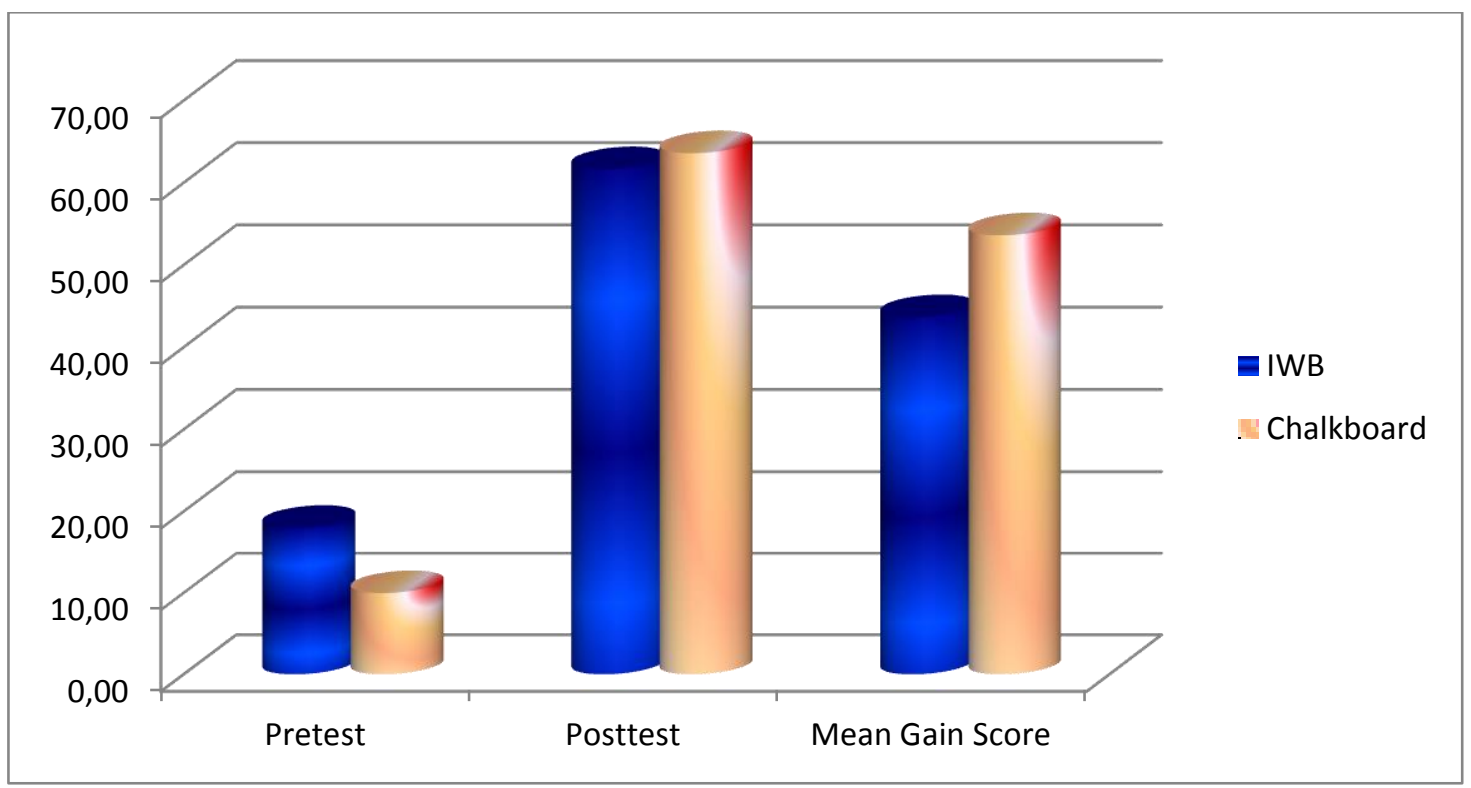

Figure 1. Graphical Illustration of Students Exposed to IWB and Chalkboard

Hypothesis Two: There is no significant difference in the mean achievement scores of male and female students taught Basic Technology using Interactive Whiteboard.

To determine whether there was significant difference in the post-test mean scores of male and female students using IWB, data were analyzed using the analysis of covariance (ANCOVA). The results of the analysis are shown in Table 5.

Table 5. ANCOVA of Post-test on Male and Female Students in IWB Group

\begin{tabular}{llllll}
\hline $\begin{array}{l}\text { Source of } \\
\text { Variation }\end{array}$ & Sum of Square & df & $\begin{array}{l}\text { Mean } \\
\text { Square }\end{array}$ & $F$ & Significance \\
\hline $\begin{array}{l}\text { Covariate } \\
\text { (Pretest) }\end{array}$ & 3279.717 & 1 & 3279.717 & 34.997 & 0.000 \\
$\begin{array}{l}\text { Main Effect } \\
\text { (Gender) }\end{array}$ & 159.013 & 1 & 159.013 & 1.697 & 0.200 \\
Model & 3288.297 & 2 & 1644.148 & 17.544 & 0.000 \\
Residual & 3936.014 & 42 & 93.715 & & \\
Total & 178226.000 & 45 & & & \\
\hline
\end{tabular}

Table 5 shows that, main effect of treatment group (IWB) on gender produced an $F(1,42)=$ $1.697, p=>.05$. This result was not significant at the 0.05 alpha level. This indicates no significant difference in the performance of male and female students exposed to IWB. The hypothesis two is therefore not rejected. This implies that male students' achievement did not differ significantly from that of female students when both were taught using IWB. 
The mean gain scores between the pretest and posttest among male and female in the computer-supported IWB group were tabulated and graphically illustrated as shown in Table 6 and Figure 2 respectively.

Table 6. Mean Gain Scores of Male and Female in IWB Group

\begin{tabular}{llll}
\hline Group & Pre-test & Post-test & Mean Gain Score \\
\hline Male & 19.04 & 62.09 & 43.05 \\
Female & 17.00 & 61.22 & 44.22 \\
\hline
\end{tabular}

Table 6 shows that male students had mean gain scores of 43.05 while the female students had mean gain scores of 44.22 . This indicates that both groups benefited from the treatment, with female students slightly performed better than male students. Furthermore, the comparison in the mean scores between their pre-test and post-test is shown in Figure 2.

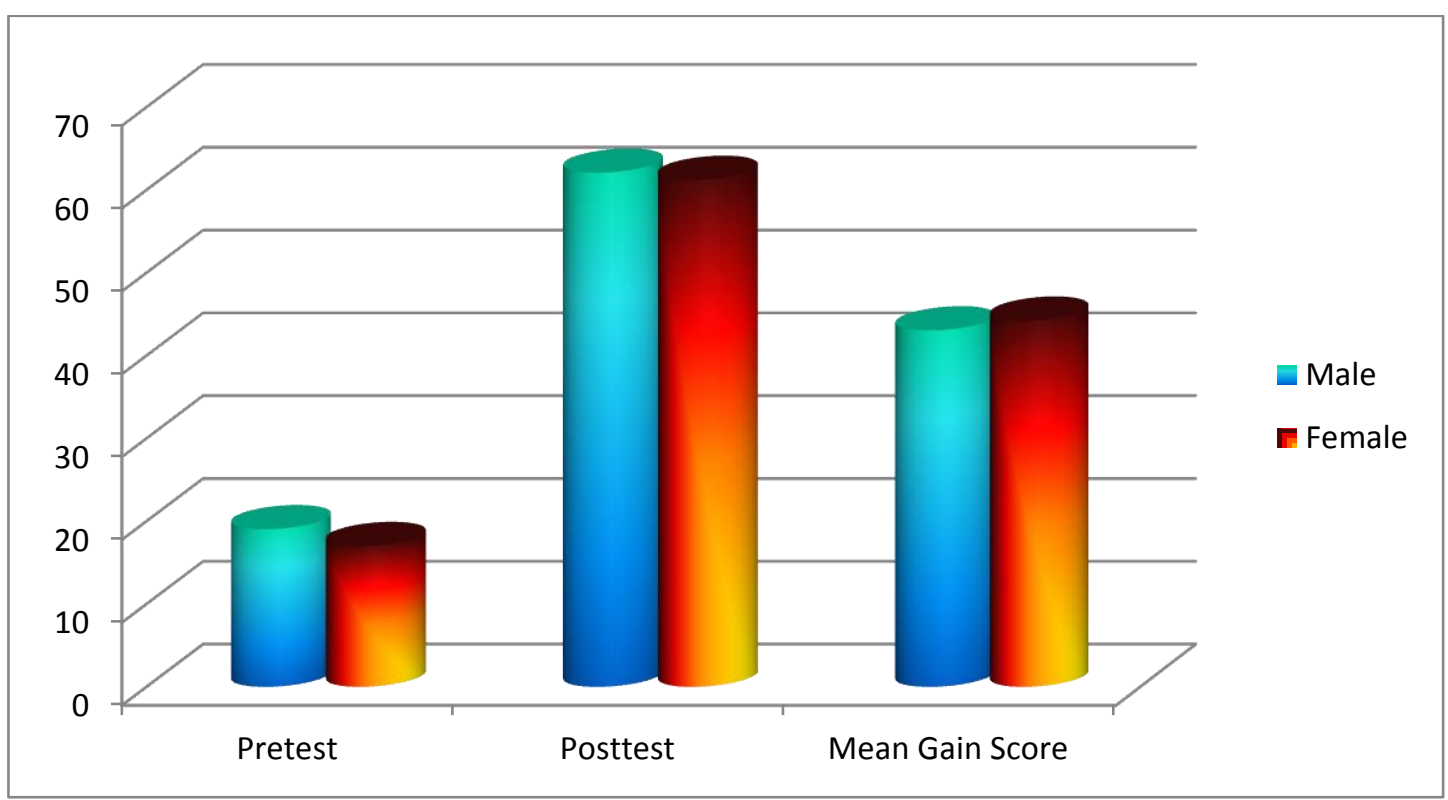

Figure 2. Graphical Illustration of Male and Female Students Exposed to IWB

Hypothesis Three: There is no significant difference in the mean achievement scores of high, medium and low achiever students using Interactive Whiteboard.

To determine whether there was significant difference in the posttest mean scores of the IWB, data were analyzed using the analysis of covariance (ANCOVA). Table 7 shows analysis of the result. 
Table 7. ANCOVA of Post-test on High, Medium and Low Achievers in IWB Group

\begin{tabular}{lllllc}
\hline $\begin{array}{l}\text { Source of } \\
\text { Variation }\end{array}$ & Sum of Square & $\mathrm{df}$ & $\begin{array}{l}\text { Mean } \\
\text { Square }\end{array}$ & $\mathrm{F}$ & Significance \\
\hline $\begin{array}{l}\text { Covariate } \\
\text { (Post-test) }\end{array}$ & 742.101 & 1 & 742.101 & 10.857 & 0.002 \\
$\begin{array}{l}\text { Main Effect } \\
\text { (Level) }\end{array}$ & 1292.632 & 2 & 646.316 & 9.456 & 0.000 \\
Model & 4421.916 & 3 & 1473.972 & 21.565 & 0.000 \\
Residual & 2802.395 & 41 & 68.351 & & \\
Total & 178226.000 & 45 & & & \\
\hline
\end{tabular}

Table 6 indicates that $F(1,41)=9.456, p=<.05$ for the main effect was significant at 0.05 alpha level. This indicates that there were significant difference in the posttest mean scores of the high, medium and low achiever students. This implies that the use of IWB was influenced by the achievement levels as the initial advantage at the pretest had been statistically controlled using ANCOVA.

A post-hoc analysis using Scheffe test was conducted to determine the direction of difference among the three achievement levels. The result of the analysis is shown in Table 8.

Table 8.Scheffe's Post-hoc Analyses of the Groups' Mean Scores

\begin{tabular}{lllll}
\hline Groups & $\begin{array}{l}\text { Mean } \\
\text { Scores }\end{array}$ & $\begin{array}{l}\text { Group I } \\
\text { (High) }\end{array}$ & $\begin{array}{l}\text { Group II } \\
\text { (Medium) }\end{array}$ & Group III (Low) \\
\hline Group I (High) & 72.21 & & ${ }^{*} 0.007$ & ${ }^{*} 0.000$ \\
Group II (Medium) & 61.52 & $*^{*} 0.007$ & $*_{0.001}$ \\
Group III (Low) & 47.10 & ${ }^{*} 0.000$ & ${ }^{*} 0.001$ & \\
\hline
\end{tabular}

* The mean difference is significant at the 0.05 level.

The result in Table 8 indicates significant difference in the posttest mean scores of high achievers $(X=72.21)$ and medium achievers $(X=61.52)$ in favor of high achievers. It also indicates significant difference in the posttest scores between medium achievers $(X=61.52)$ and low achievers $(X=47.10)$ in favor of medium achievers. Significant differences was established in the posttest mean scores between high achievers $(X=72.21)$ and low achievers $(X=47.10)$ in favor of high achievers.

Table 9. Mean Gain Scores of High, Medium and Low Achievers in IWB Group

\begin{tabular}{llcc}
\hline Group & Pretest & Posttest & Mean Gain Score \\
\hline High & 20.36 & 72.21 & 51.85 \\
Medium & 18.05 & 61.52 & 43.47 \\
Low & 14.60 & 47.10 & 32.50 \\
\hline
\end{tabular}


Table 9 shows that high, medium and low achievers benefited from the treatment. However, there was difference in the mean gain scores of different achievers exposed to IWB treatment. The high achievers had 51.85 mean gain scores, followed by medium achievers with mean gain scores of 43.47 and low achievers with 32.50 as mean gain scores. This implies that all the groups benefited from the treatment, with high achievers having better mean gain score than medium and low achievers. The mean gain scores of the three achievement levels are further shown in Figure 3.

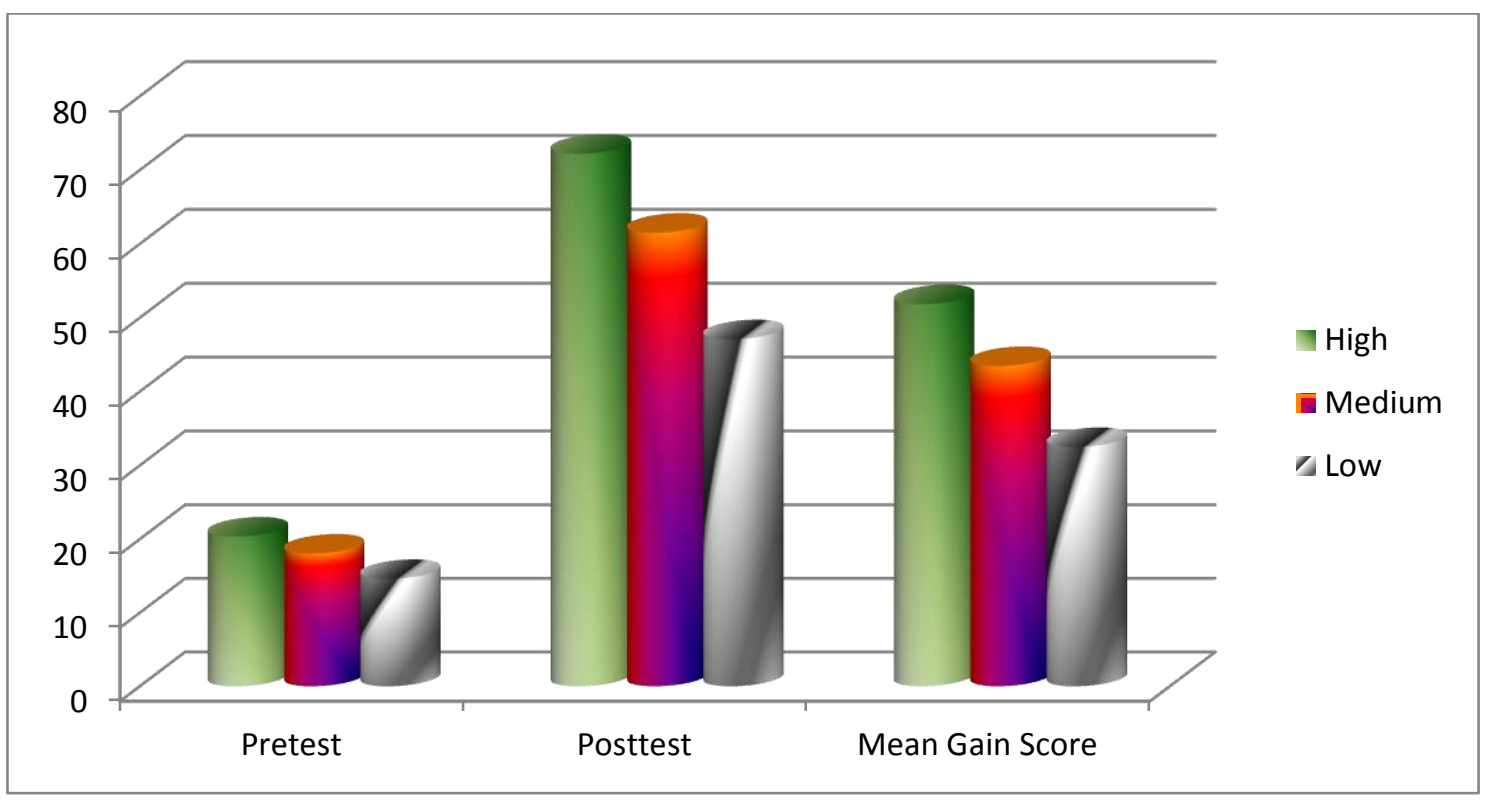

Figure 3.Graphical Illustration of High, Medium and Low Achievers Exposed to IWB

\section{Discussion of Results}

The results of hypothesis one reveals that there is a significant difference in the learning achievements in favor of the group taught isometric and orthographic projection concept with IWB. This result agrees with the findings of Zittle (2004) in geometry, Dhindsa and Emran (2006) in organic chemistry, Wood and Ashfield (2008) in literacy and numeracy, and Miller, Glover, and Averis (2003) in Mathematics which confirmed that IWB has been effective in enhancing students' performance than conventional classroom instruction. However, the findings disagree with Buff (2012) who investigated the effects of interactive whiteboards on students' achievement. In the end, the control group consistently scored higher on the assessment piece than experimental group. It also disagrees with the findings of Christophy and Wattson (2007), Schuck and Kearney (2007), Glover et al., (2005b); Martin, (2007); Smith et al., (2005) and Solvie, (2007). The higher achievement by the experimental group could be attributed to the novel nature of IWB in the Nigerian school setting and hence was able to captivate the attention of the students. It can also be attributed to the fact that IWB implore the use of various stimuli (images, sounds and movement) and address the needs of diverse types of learning (visual, psychomotor, and affective).

The results of hypothesis two shows that there is no gender effect on the achievement of male and female students taught isometric and orthographic projection concepts with IWB. This finding is in agreement with the results of Annetta, Mangrum, Holmes, Collazo and Cheng 
(2009), Kost, Pollock and Finkelstein (2009), Ifamuyiwa and Akinsola (2008), and Gambari (2010) revealed that there is no significant difference in the performance of male and female students in mathematics and physics concepts respectively.

The results of hypothesis three reveals that there is a significant difference in the mean achievements in favor of the high achievers taught isometric and orthographic projection concept with IWB. This result agrees with the findings of Aluko (2004) in chemistry, Fajola (2000) in biology, Gambari (2010) in physics and Yusuf (2004) in social studies which revealed that high ability students do perform better than the medium and lower ability students.

\section{Conclusion}

The paper has critically examined basic technology education and its problems especially within the secondary school level in a rapidly changing world. It is the view of the authors that there is still a wide gap to be bridged in the area of e-teaching. The innovative technology using IWB seems to be the answer. The use of IWB for practical demonstration and students' participation was more effective in teaching isometric and orthographic projection concepts, and is also gender friendly. Finally, students' achievement level could influence his or her achievement towards learning when IWB is use.

\section{Recommendations}

In this space age, Nigeria schools and educators are expected to be in the vanguard to propel the use of various ICT tools in promoting effective teaching and learning in schools. Therefore, it is recommended that the use of IWB should be encouraged in Nigerian schools especially for teaching technological based and other practical oriented courses. This could be achieved if government and other education stakeholders could provide IWB to schools with adequate infrastructure and training of teachers on its usage.

\section{References}

Abassa, M. (2011). Analysis of problems and prospects of the technical college teachers in Nigeria. Proceedings of the 2011 International conference on teaching and learning and change. International Association for Teaching and Learning (IATEL).

Ajani, S. M. (2009). Effects of workshop practices on students' performance in introductory technology (Unpublished Manuscript). Imo State University, Owerri.

Akpan, G. A., Udofia, A. E., \& Mbaba, U. G. (2012). Influence of students, understanding and goal commitment on academic achievement in Introductory Technology in Akwa Ibom state Nigeria. International Education Studies, 5(2), 12-20.

Aluko, K. O. (2004). Effects of cooperative and individualistic instructional Strategies on students problem solving abilities in secondary school chemistry in llesa (Unpublished doctoral dissertation). CSET Department University of Ilorin, Nigeria.

Anagbogu, M. A. \&Ezeliora, B. (2007).Sex differences and scientific performance. Women Journal of Science and Technology,4, 10-20. 
Annetta, L., Mangrum, J., Holmes, S., Collazo, K., \& Cheng, M. (2009). Bridging realty to virtual reality: Investigating gender effect and student engagement on learning through video game play in an elementary school classroom. International Journal of Science Education, 31(8), 1091-1113.

Aregbesola, R. (2013). Opon imo - tablet of knowledge. Retrieved fromhttp://www.wsisaward.org/winner/opon-imo-tablet-knowledge-108120130905

Balogun, S. A. (2007). Assessment of the implementation of introductory technology in Suleja, Tafa and Gurara local government of Niger state (Unpublished doctoral dissertation). Federal University of Technology, Minna.

Beauchamp, G. (2004). Teacher use of the interactive whiteboard (IWB) in primary schools towards an effective transition framework. Technology, Pedagogy and Education, 13, 329-349.

Becta (2003). What research says about interactive white boards? Coventry: Becta. Retrieved 20 March 2010 fromhttp://www.becta.org.uk/page_documents/research/ wtrs_whiteboards.pdf

Buff, D. D. (2012). Investigating the effects of interactive whiteboards on student achievement. A dissertation submitted to the Faculty in the Curriculum and Instruction Program of Tift College of Education at Mercer University.

Christophy, E. \& Wattson, E. (2007). The effect of interactive whiteboards on student learning in the chemistry classroom. Retrieved on 20 October 2014 from http://digitalcommons. liberty.edu/cgi/viewcontent.cgi?article $=1140 \&$ context=doctoral

Dhindsa, H. S. \&Emran, S. H. (2006, March). Use of the interactive whiteboard in constructivist teaching for higher student achievement. Proceedings of the Second Annual Conference for the Middle East Teachers of Science, Mathematics, and Computing, Held at Abu Dhabi (pp. 175-188).

Fajola, O. O. (2000). Effect of three modes of computer based instructional strategies on students learning outcomes in biology (Unpublished doctoral dissertation). Department of Teachers' Education, University of Ibadan.

Federal Republic of Nigeria (FRN), (2009).National policy on education. Abuja: Nigerian Educational Research and Development Council (NERDC).

Gambari, I. A. (2010).Effect of computer-supported cooperative learning strategies on the performance of senior secondary students in physics in Minna, Nigeria (Unpublished doctoral dissertation). University of Ilorin, Ilorin, Nigeria.

Glover, D. \& Miller, D. (2001).Running with technology: The pedagogic impact of the large scale introduction of interactive whiteboards in one secondary school. Journal of Information Technology for Teacher Education, 10, 257-276.

Glover, D., Miller, D., Averis, D., \& Door, V. (2005b). The interactive whiteboard: A literature survey. Technology, Pedagogy \& Education, 14(2), 155-170.

Higgins, S., Beauchamp, G., \& Miller, D. (2007).Reviewing the literature on interactive whiteboards. Learning, Media and Technology, 32(3), 213-225.

Higgins, S. E. (2010). The impact of interactive whiteboards on classroom interaction and learning in primary schools in the UK. In Interactive whiteboards for education: Theory, research and practice (pp. 86-101). Hershey PA: IGI Global. 
Ifamuyiwa, S. A. \& Akinsola, M. K. (2008).Improving senior secondary school students' attitude towards Mathematics through self and cooperative-instructional strategies.

International Journal of Mathematical Education in Science and Technology, 39(5) 569585. (EJ799217).

Jones, K. (2004). Using interactive whiteboards in the teaching and learning of mathematics: A research bibliography. Micromath, 20(2), 5-6.

Kennewell, S. \& Beauchamp, G. (2003).The influence of a technology-rich classroom environment on elementary teachers' pedagogy and children's learning. In J. Wright, A. McDougall, J. Murnane\& J. Lowe (Eds.), Young children and learning technologies (pp. 65-70). Sydney: Australian Computer Society.

Kiadese, L. A (2011). An assessment of the teaching effectiveness of prevocational subjects teachers in Ogun state Nigeria. International Journal of Vocational and Technical Education, 3(1), 5-8.

Kost, L. E., Pollock, S. J. \& Finkelstein, N. D. (2009). Characterizing the gender gap in introductory physics (EJ826790). Physics Education Research, 5(1) 1-14.

Lerman, S. \& Zevenbergen, R. (2006). Maths, ICT\& pedagogy: An examination of equitable practice across diverse settings. In J. Novotna, H. Morova, M. Kratka, \& N. Stehlikova (Eds.) Mathematics in the centre proceedings of the 30th annual conference of the International Group for the Psychology of Mathematics Education (Vol. 4, pp. 49-56). Prague: PME.

Levy, P. (2002).Interactive whiteboards in learning and teaching in two Sheffield Schools: A developmental study. Sheffield Department of Information Studies, University of Sheffield. Retrieved on 15 July 2004 from http://dis.shef.ac.uk/eirg/projects/wboards. htm

Martin, S. (2007). Interactive whiteboards and talking books: A new approach to teaching children to write? Literacy, 41(1), 26-34.

McNeese, M.N. (2003). Acquisition and Integration of SMART board interactive whiteboard skills: Gender differences among college faculty, staff and graduate assistants. Retrieved on 23 March 2012 from www.smarterkids.org/research/pdf/McNeese.pdf.

Miller, D., Glover, D., \& Averis, D. (2003, March). Exposure-The introduction of interactive whiteboard technology to secondary school mathematics teachers in training. Paper presented at CERME3: Third Conference of the European Society for Research in Mathematics Education. Bellaria, Italy.

National Examination Council (NECO). (2007, 2008, 2009, 2010, \&2012). Chief examiners' reports. Minna. Research and Statistics Unit.

Olowoopejo, M. (2014). Fashola commissions Lagos version of Opon-imo. Vanguard Newspaper, March 14. Retrieved from http://www.vanguardngr.com/2014/03/fasholacommissions-lagos-version-opon-imo/\#sthash.MsFhFbmt.dpuf

Painter, D. D., Whiting, E., \& Wolters, B. (2005).The use of an interactive whiteboard in promoting interactive teaching and learning. VSTE Journal, 19(2), 31-40. 
Schuck, S. \& Kearney, M. (2007).Exploring pedagogy with interactive whiteboards: A case study of six schools (Sydney, University of Technology Sydney). Available online at: http://www.ed-dev.uts.edu.au/teachered/research/iwbproject/pdfs/iwbreportweb.pdf

Smith, F., Hardman, F., \& Higgins, S. (2006). The impact of interactive whiteboards on teacherpupil interaction in the national literacy and numeracy strategies. British Educational Research Journal, 32(3), 443-457.

Smith, H., Higgins, S., Wall, K., \& Miller, J. (2005). Interactive whiteboards: Boon or bandwagon? A critical review of the literature. Journal of Computer Assisted Learning, 21(2), 91-101.

Solvie, P. (2007). Leaping out of our skins: Postmodern considerations in use of an electronic whiteboard to foster critical engagement in early literacy lessons. Educational Philosophy \& Theory, 39(7), 737-754.

Winzenried, A, Dalgano, B, \& Tinkler, J. (2010). The interactive whiteboard: A transitional technology supporting diverse teaching practices. Australian Journal of Educational Technology, 26(4).

Wood, R. \& Ashfield, J. (2008). The use of the interactive whiteboard for creative teaching and learning in literacy and mathematics: A case study. British Journal of Educational Technology, 39(1), 84-96.

Yanda, M. B. (2012). Assessment of secondary school students and teachers attitudes' towards the use of interactive whiteboard for teaching and learning in Niger State, Nigeria. (Unpublished thesis). Federal University of Technology, Minna, Nigeria.

Yoloye, E. A. (1990). Use and perception of computers by educationists at the University of Ibadan. Ilorin Journal of Education, 10(2), 90-97.

Yusuf, A. (2004). Effects of cooperative and competitive instructional strategies on junior secondary school students' performance in social studies, in Ilorin, Nigeria (Unpublished doctoral dissertation). Curriculum Studies and Educational Technology, University of Ilorin, Nigeria

Yusuf, M. O., Gambari, A.I., \& Olumorin, C. O. (2012). Effectiveness of Computer-Supported Cooperative Learning Strategies in Learning Physics. International Journal of Social Sciences and Education, 2(2), 94-109.

Zittle, F. J. (2004). Enhancing Native American mathematics learning: The use of Smartboardgenerated virtual manipulatives for conceptual understanding. Retrieved on 8 October 2007 fromhttp://edcompass.smarttech.com/NR/rdonlyres/3E2A063B-6737-400F-BD071D239C428729/0/Zittle.pdf

Xu, H. \& Moloey, R. (2011). It makes the whole learning experience better: Student feedback on the use of the interactive whiteboard in learning Chinese at tertiary level. Asian Social Science, $7(11)$.

Correspondence: Isiaka A. Gambari, Senior Lecturer, Science Education Department, Federal University of Technology, Minna, Nigeria 